\title{
Danske domstole mellem tradition og fornyelse
}

Michael Gøtze Lektor ph.d., Det Juridiske Fakultet, Københavns Universitet

Den seneste domstolsreform har aktualiseret den vigtige målsætning om åben rekruttering af dommere til danske domstole. Selv om landkortet over danske domstole har ændret sig markant de senere år, er den efterhånden over 10 år gamle målsætning fra politisk hold om alsidig dommerrekruttering dog endnu ikke implementeret. Selv om spørgsmålet om fornyelse af dommerrekrutteringen er kontroversielt, ikke mindst i domstolssystemet selv, er der grund til at holde fast $\mathrm{i}$, at danske domstole skal opfylde målet om bred rekruttering af dommere fra det juridiske fagmiljø for dermed at sikre sin position som uafhængig statsmagt.

\section{Dommerrekruttering i retlig tidsalder}

Domstolene spiller en vigtig rolle i det danske samfund, og både politikere, medier og befolkning synes mere og mere fokuseret på retssager og retsstof. Der er mange årsager til denne udvikling, men det er på det overordnede plan uden tvivl af betydning, at der sker en retliggørelse af mange livs- og samfundsområder i disse år. Politiske og andre spørgsmål bliver således gjort til genstand for retlig regulering og retlig bedømmelse som følge af en stigende lovproduktion med bl.a. den konsekvens, at domstolssystemet får en stadig mere central placering som konfliktløsningsforum i sociale, økonomiske og politiske sammenhænge.

Til trods for en stigende retliggørelse lever danske domstole dog fortsat ofte et liv i skyggen. Sammenlignet med de to andre statsmagter, den lovgivende magt - Folketinget - og den udøvende magt - regeringen og forvaltningen - indtager den dømmende magt - domstolene - i udpræget grad rollen som den anonyme statsmagt. Stigende mediefokus på spektakulære enkeltsager ved domstolene især inden for det strafferetlige område og en generel opprioritering af retspolitiske temaer trækker selvsagt i den modsatte retning, men i det samlede billede af de tre øverste statsmagter i en retlig tidsalder er domstolssystemet stadig ofte undereksponeret.

Denne undereksponering gælder ikke mindst det principielle spørgsmål om bred rekruttering af jurister til stillinger som dommer. Dommerne er det faglige omdrejningspunkt i domstolssystemet, da de træffer de endelige afgørelser i de konkrete retssager. Det er derfor ikke uden betydning, hvem der bliver udnævnt som dommere. Der blev på dette område taget en række politiske initiativer for 10 år siden med henblik på at ændre og modernisere en relativt fastlåst og lukket rekruttering af nye dommere. Der var enighed blandt politikerne om et entydigt mål om alsidig rekruttering, da domstolenes legitimitet som system hænger nøje sammen med, at de både reelt er og rent optisk fremtræder som uafhængige og upåvirkede af andre statsmager. Også på et praktisk plan er en bredt forankret rekruttering vigtig, da det er velkendt, at mange konkrete domstolsafgørelser ikke er resultater af mekanisk anvendelse af jura, men ofte i høj grad beror på dommerens individuelle vurderinger og afvejninger pro et contra. De jurister, som udnævnes til dommerne, bør derfor så vidt muligt afspejle et bredt udsnit af den juridiske profession.

Diskussionen om alsidig rekruttering er imidlertid blevet glemt i den reform af domstolssystemet, som for tiden er ved at blive realiseret i landets forskellige domstole. I 2007 blev landkortet over retskredse således nytegnet i en omfattende strukturel og faglig reform, som også 
udløste et stort antal nye dommeransættelser. Men det skete $u$ den diskussion af rekrutteringen. Den glemte diskussion er bemærkelsesværdig i lyset af både domstolenes generelle samfundsmæssige indflydelse og af den simple grund, at den brede rekruttering endnu ikke ses at være realiseret. Det vil fremgå af det følgende, hvor sigtet er at beskrive udviklingen de seneste år og at trække forskellige træk af dommerkulturen frem. Den snævre rekruttering lever - trods mindre men dog interessante fremskridt på visse enkeltområder - fortsat videre, og jurister fra især Justitsministeriet har fortsat et godt tag i domstolene.

\section{Rekrutteringsreform i Tamil-sagens skygge}

Den politiske målsætning om alsidig dommerrekruttering går tilbage til 1998, da Folketinget vedog en række ændringer af det eksisterende domstolssystem for at sikre en betydelig mere åben rekrutteringskultur. Samtlige politiske partier i Folketinget støtter daværende justitsminister Frank Jensens (S) forslag om en rekrutteringsreform, som til og med bliver sat på en juridisk formel i retsplejeloven $(\$ 43)$. Den nye regel proklamerer, at muligheden for en dommerkarriere skal stå åben for alle kvalificerede jurister uanset baggrund. I forhold til den samlede kreds af dommere et det et mål i sig selv, at der tilstræbes erhvervsmæssig forskelligartethed. Diversitet er med andre ord mantraet. Som led i en institutionel reform af udnævnelsessystemet bliver der i 1999 endvidere oprettet et nyt og formelt uafhængigt organ, nemlig det såkaldte Dommerudnævnelsesråd bestående af et kollegium af jurister og offentlighedsrepræsentanter. Rådet har til opgave at bedømme ansøgere til dommerstillinger og at afgive indstilling til Justitsministeren om besættelse af ledige stillinger. Selv om det er ministeren, der formelt har det sidste ord, følger ministeren i praksis altid rådets indstillinger.

I den politiske debat i 1990'erne er der meget fokus på de principielle aspekter af rekrutteringsproblematikken. I kølvandet på den historiske Tamil-sag og politikernes og mediernes efterfølgende fokus på navnlig Justitsministeriets magtposition er rekruttering uden videre et „hot"emne. Den efterhånden så famøse politiske og administrative nedprioritering af asylansøgninger fra herboende tamilske flygtning afslører en betænkelig magtfuldkommenhed i Justitsministeriet, som kulminerer med Rigsretssagen mod den ansvarlige minister. I kølvandet på ministeriets legitimitetskrise opstår den politiske og juridiske diskussion om Justitsministeriets traditionelt tætte bånd til domstolene.

Under forarbejdet med det nye udnævnelsessystem fremhæver mange folketingspolitikere, at rekrutteringsreformen drejer sig om „en synliggørelse af domstolenes uafhængighed“ som anført af Birte Rønn Hornbech fra
Venstre (under førstebehandlingen af lovforslaget 2. april 1998). Synspunktet er altså, at der for så vidt ikke er noget aktuelt problem med magtens tredeling mellem lovgivende, udøvende og dømmende magt, men at der er behov for en understregning af, at domstolene ikke kun er men også fremtrader som uafhængige af navnlig Justitsministeriet. Inden rekrutteringsreformen er det netop Justitsministeriet, der administrerer domstolene, samtidig med, at mange dommere har deres professionelle opvækst i Justitsministeriet. Dobbeltrollerne er oplagte. En synliggørelse af domstolenes uafhængighed skal ske ved at skabe og sikre andre rekrutteringskanaler ind i dommerembedet end en karriere i Justitsministeriet. Der er også mere kritiske røster fremme i debatten på dette tidspunkt, og f.eks. Dansk Folkeparti peger på, at det er direkte stødende for retsbevidstheden, hvis magtbaserne i staten hænger sammen, og hvis der sker en næsten automatisk rekruttering af dommere fra Justitsministeriet. „Vi må nok erkende, hvis vi med vores politiske holdning i Dansk Folkeparti ser på tingene, er der da afgørelser ved domstolene, hvor man ikke kan udelukke, at der har været tale om en slags korrumperende magt" (Peter Skaarup, også under førstebehandlingen af lovforslaget).Under det politiske og juridiske forarbejde med rekrutteringsreformen bliver det fra både politikere og domstolssystem påpeget, at en rekrutteringsreform ikke må ske på bekostning af fagligheden. „Det afgørende er ... at vi rekrutterer de absolut bedste jurister til dommerstillingerne" (Bendt Bendtsen, Konservative Folkeparti). Dette mål om højst mulig faglig kompetence i dommerkorpset er alle røster i debatten - både i det politiske og juridiske miljø - enige om både før og efter reformen fra 1998.

Til grund for den politiske debat ligger en sagkyndig betænkning fra 1996 fra det såkaldte Domstolsudvalg med deltagelse af en bred kreds af repræsentanter fra det juridiske fagmiljø. Også denne betænkning er værd at huske i dag. Udvalgets betænkning er et digert værk på over 600 sider, som lægger op til en anden model end den traditionelle snævre rekruttering af dommere fra domstolene selv og Justitsministeriet. Konkret peger Domstolsudvalget på, at langt de fleste dommere i 1990'erne er uddannet ved domstolene som dommerfuldmægtige (62\%) eller i Justitsministeriets regi (33\%). På dette tidspunkt er rekrutteringen således funderet i hvad der kaldes en dommerkarrieremodel. Ifølge Domstolsudvalgets opgørelser fra 1996 kommer de resterende dommere fra politi- og anklagemyndighed ( $4 \%$ ) og fra advokat- og/eller universitetsbranchen (1\%). I alt har $95 \%$ af dommerstanden på dette tidspunkt med andre ord karrierebaggrund fra domstolene eller Justitsministeriet. Denne høje andel af jurister med en bestemt karrieremæssig profil betyder i Domstolsudvalget øjne, at rekrutteringen er for fastlåst. 
Det kan nævnes, at juristerne fra domstolene og juristerne fra Justitsministeriets departement traditionelt har fordelt sig efter et bemærkelsesværdigt fast geografisk mønster i forhold til de forskellige retsinstanser. Justitsministeriets jurister er typisk blevet udnævnt til dommere i Københavns Byret, Østre Landsret og Højesteret, mens de domstolsuddannede jurister, dvs. dommerfuldmægtigene, typisk er blevet udnævnt som dommere ved byretterne i provinsen. Det har tidligere været et bemærkelsesværdigt gennemgående træk, at mange dommere fra Københavns Byret senere er blevet forfremmet til landsdommere i Østre Landsret (Jens Peter Christensen, 2003).

Den substantielle indvending i Domstolsudvalgets betænkning mod en snæver rekruttering er, at dommere skoles og præges på en bestemt måde gennem deres forudgående ansættelse i f.eks. Justitsministeriet. Dette synspunkt fremføres og nuanceres af et mindretal i udvalget. Skolingen antages at udmønte sig i systemvenlighed i civile sager og straffesager. Dommerne antages at være og vil i hvert fald altid kunne opfattes som mere lydhøre over for offentlige myndigheders synspunkter end f.eks. borgeres og private virksomheders synspunkter. I straffesager består systemvenligheden $\mathrm{i}$, at dommerne antages at være mere venligt stemt over for anklageren end forsvareren. Et flertal i udvalget mener imidlertid ikke, at der er fare for sådan systemvenlighed. De peger på, at det tværtimod kan være en fordel med dommere, der kender systemet indefra. Et flertal i udvalget støtter dog tanken om alsidighed i rekrutteringen, og uanset de forskellige begrundelser for alsidig rekruttering er udvalgsflertallet altså enige om diversitet som lovfæstet mål.

\section{Aktuelle rekrutteringsmønstre - hvad er status?}

Den nye domstolsreform fra 2007 har ført et stort antal nye dommerstillinger med sig. Formålet med den nye reform har dog primært været at nytænke strukturen i domstolssystemet ved at skabe nye og større byretskredse, idet stordrifts- og fusionstænkning med reformen nu også har indhentet domstolene. Hertil kommer en indholdsmæssig og faglig modernisering af domstolenes arbejde. En grundpræmis for den faglige reform er, at de stadig mere komplekse juridiske tvister er en udfordring til domstolene og dommere på alle niveauer. Som led i implementering af reformen er især byretterne - det laveste domstolsniveau - derfor gjort fagligt mere robuste ved hjælp af mange nye dommerudnævnelser. En vigtig nyskabelse er, at byretterne i vidt omfang nu har fået mulighed for at bestemme, at en konkret sag skal behandles af tre dommere, og ikke kun en enkelt byretsdommer. Dette vender jeg tilbage til.
Fra 2006 til 2008 er der indsluset over 100 jurister til nye dommerstillinger på de tre domstolsniveauer: byret, landsret og Højesteret. Selv om de mange nye dommeransættelser har aktualiseret betydningen af den lovfæstede målsætning om diversitet i rekrutteringen, kan det konstateres, at diskussionen om dommerrekruttering har glimret ved sit fravær i store dele af den faglige debat op til reformen i 2007. Man spejder således forgæves efter en diskussion af rekrutteringen i de fem bind, som udgør grundstoffet i den nye reform (reform af den civile retspleje I-V, afgivet af Retsplejerådet fra 2001-2006). Det er dog værd at fastholde, at målet om bred rekruttering $i k k e$ er opgivet.

I den forbindelse har den heftige debat i 2008/09 i Danmark om vedtagelse af et lovforbud mod brug af tørklæde i retssalen berørt spørgsmålet om rekruttering. Implicit har denne politiske debat bygget på en forudsætning om etnisk diversitet i dommerkorpset, idet målgruppen for tørklædeforbuddet åbenlyst har været kvindelige dommere med muslimsk baggrund. Det er interessant, at der indtil videre ikke ses at være indstillet og udnævnt en eneste kvindelig dommer med denne etniske profil i Danmark. Uanset dette faktum har et bredt flertal i Folketinget vedtaget en ændring af retsplejeloven, således at der med virkning fra 1. juli 2009 gælder et forbud mod juridiske fagdommeres brug af tørklæde.

Hermed er vi inde i den aktuelle udvikling i dommerrekrutteringen. Et indledende overblik over væksten i nyudnævnelser de senere år kan fås i den følgende figur, som primært bygger på tal fra Dommerudnævnelsesrådet (www.domstol.dk). Ifølge de senest tilgængelige oplysninger (maj 2008) er der nu i alt 263 dommere i Danmark. Der var i maj 2008 udmøntet 241 ud af de 253 stillinger, der skal være ved landets byretter, når domstolsreformen af 2007 er fuldt implementeret.

Tabel 1. Udnævnelser af dommere til almindelige domstole (byretter, landsretter, Sø- og Handelsret og Højesteret)

\begin{tabular}{|l|c|c|c|c|c|c|}
\hline & 2003 & 2004 & 2005 & 2006 & 2007 & 2008 \\
\hline Udnæunelser i alt & 18 & 16 & 13 & 43 & 34 & 22 \\
\hline Byret & 11 & 11 & 6 & 39 & 31 & 17 \\
\hline Landsret og SH & 6 & 4 & 6 & 2 & 3 & 5 \\
\hline Højesteret & 1 & 1 & 1 & 2 & 0 & 0 \\
\hline
\end{tabular}

\section{Erhvervsmæssig diversitet}

Den erhvervsmæssige diversitet blandt landets nye dommere fremgår af Dommerudnævnelsesrådets statistiske tabeller og „lagkager“ i rådets årsberetninger. Her formid- 
les et udvalg af generelle oplysninger om de førstegangsudnævnte dommeres karrierebaggrund og erhvervsprofil. Oplysningerne vedrører dommernes samlede professionelle løbebane som jurister, bortset fra at ansættelsesperioder under 1 års varighed er helt fravalgt. Udviklingen i hovedtræk kan ses i den følgende oversigt.

Tabel 2: Dommerudnævnelser 2003-2008 fordelt efter de nye dommernes primære erhvervsbaggrund

\begin{tabular}{|l|r|r|r|r|}
\hline & Byret & $\begin{array}{c}\text { Landsret } \\
\text { og SH }\end{array}$ & $\begin{array}{c}\text { Højeste- } \\
\text { ret }\end{array}$ & Samlet \\
\hline Dommerfuldmægtig/dommer & $81 \%$ & $35 \%$ & $20 \%$ & $71 \%$ \\
\hline Advokat & $10 \%$ & $19 \%$ & $20 \%$ & $12 \%$ \\
\hline Politi- og anklagemyndighed & $1,5 \%$ & $4 \%$ & $0 \%$ & $2 \%$ \\
\hline Procesbevillingsnævn etc. & $0 \%$ & $4 \%$ & 0 & $1 \%$ \\
\hline Justitsministeriet med institutioner & $6 \%$ & $35 \%$ & $40 \%$ & $12 \%$ \\
\hline Anden offentlig ansættelse & 0 & $4 \%$ & 0 & $1 \%$ \\
\hline Universitetsansættelse & $0 \%$ & $0 \%$ & $20 \%$ & $1 \%$ \\
\hline $\begin{array}{l}\text { Anden privat ansættelse end } \\
\text { advokat }\end{array}$ & 0,5 & $0 \%$ & $0 \%$ & $1 \%$ \\
\hline
\end{tabular}

Note: Kategorien Procesbevillingsnævn etc. omfatter Procesbevillingsnævnet og Domstolsstyrelsen

For så vidt angår systematiseringen af de forskellige ansættelsesområder, belyser min oversigt først de fire ansættelsesområder, som præsumptivt giver de bedste muligheder for praktisk erfaring med retssager. Det gælder med andre ord jurister, der er ansat ved domstolene selv som dommerfuldmægtige/retsassessorer, hvortil kommer jurister med baggrund fra advokatbranchen, politi- og anklagemyndigheden og Procesbevillingsnævnet. Herefter følger i figurens nederste halvdel de fire ansættelsesområder, som også indeholder substantielt juridisk arbejde af forskellig art, men dog typisk ikke arbejde i længere tid med egentlige retssager. Den valgte struktur er inspireret af oplysningerne fra det norske dommerudnævnelsesråds („Innstillingsrådets") oplysninger, som på tilsvarende vis belyser de praktisk mest relevante ansættelsesområder først. Min oversigt tager udgangspunkt i de pågældende dommernes relativt længste ansættelse inden dommerudnævnelse. De fleste dommere har dog flere ansættelser bag sig, hvad der selvsagt også hører med i et nuanceret billede af udviklingen. En detaljeret gennemgang af de individuelle erfaringer falder uden for denne artikels rammer. Det er dog værd at fremhæve, at målet om bred rekruttering primært sigter til dommerstanden som sådan og det strukturelle niveau, og ikke kun de individuelle dommerprofiler.

Der er efter min opfattelse grund til at fremdrage følgende forhold fra tallene. I forhold til byretterne man kan hæfte sig ved, at langt hovedparten af de nye dommere har en fortid som dommerfuldmægtig eller retsassessor, nemlig cirka fire dommere ud af fem nye dommere. De er altså rekrutteret fra domstolssystemet selv. Det kan her bemærkes, at de domstolsuddannede dommere i modsætning hertil udgør et mindretal af dommerne i landsretterne og Højesteret. Endvidere kan det trækkes frem fra oversigtens tal om nye byretsdommere, at jurister med advokatbaggrund nu udgør den næststørste gruppe, hvad der er bemærkelsesværdigt. Dog udgør disse dommere en markant mindre andel af byretsdommerne, nemlig kun cirka $10 \%$. På tredjepladsen på byretsniveauet kommer jurister med baggrund fra Justitsministeriet med tilhørende institutioner. De udgør cirka $6 \%$ af de nye dommere. Det fremgår i øvrigt af baggrundsoplysninger fra Dommerudnævnelsesrådet, at cirka $40 \%$ af samtlige nye byretsdommere i længere eller kortere periode har haft deres gang i Justitsministeriet. Man må på det grundlag sige, at det fortsat er en klar fordel at have været ansat i Justitsministeriet, hvis man som jurist sigter mod en dommerkarriere. Endelig kan man om byretsniveauet bemærke, at der i nyere tid stort set ikke er udnævnt jurister med erfaring fra anden offentlig ansættelse (end Justitsministeriet), universitetsansættelse eller anden privat ansættelse end advokatansættelse. Hvis man samlet skal klassificere graden af diversitet i byretterne, må man sige, at der er en begrenset diversitet.

I relation til landets to landsretter og Sø-og Handelsretten har de fleste nye dommere deres betydeligste professionelle erfaring fra enten domstolssystemet selv eller Justitsministeriet. Begge grupper tegner sig for cirka $35 \%$ af udnævnelserne. Jurister med denne profil udgør samlet over $2 / 3$ af de nye dommere i landsretterne og Sø- og Handelsretten. For så vidt angår jurister fra Justitsministeriet kan det tilføjes, at en stor del af samtlige nye dommere har haft længere eller kortere ansættelse ved Justitsministeriet. Den tredje gruppe af jurister til landsretter rekrutteres nu fra advokatbranchen. På samme måde som ved byretterne er de nye dommere med advokatprofil værd at bemærke. Dog udgør de et klart mindretal, nemlig19 \%.

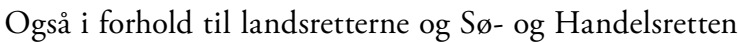
må man ud fra de statistiske oplysninger konkludere, at der er tale om en begranset diversitet.

Endelig kan det i forhold til Højesteret trækkes frem, at Dommerudnævnelsesrådet har indstillet i alt 5 jurister til prøvevotering fra 2003 til 2008. Alle er - vanen tro - blevet udnævnt. En udnævnelse vedrører en jurist med overvejende erfaring som dommer fra en lavere retsinstans. Den pågældende har endvidere været ansat i Justitsministeriets departement. En udnævnelse vedrører en jurist med overvejende erfaring fra ansættelse som advokat. Den pågældende har endvidere erfaring fra ansættelse i Justitsministeriets departement. To nyudnævnelser vedrører jurister med overvejende erfaring fra Justitsministeriet. Den ene af disse har desuden er- 
faring fra ansættelse som dommerfuldmægtig og i politi- og anklagemyndighed, mens den anden har erfaring fra ansættelse som dommerfuldmægtig, advokat og politi- og anklagemyndighed. Der er endelig udnævnt en jurist med overvejende tidligere erfaring fra ansættelse på universitet. Samlet skiller Højesteret sig ud ved at kunne dokumentere en nogenlunde klar diversitet.

Som noget nyt - og formentlig som led i et ønske om at synliggøre den seneste positive udvikling i relation til rekruttering - har Højesteret i juni 2009 anlagt en offentlighedsstrategi omkring de enkelte dommeres erhvervsprofil. Højesterets hjemmeside indeholder således nu en præsentation af samtlige fungerede dommeres curriculum vitæ. Selv om det kun er på højesteretsniveau, at sådanne oplysninger gøres tilgængelige, er der grund til at håbe, at dette mønster breder sig til andre dele af det danske domstolssystem. Byretterne og landsretter behandler således langt flere sager end Højesteret, og mange af disse sager når deres endelige afgørelse i byret eller landsret. Disse domstole er derfor af voksende betydning, og de pågældende dommerne er for parterne i de konkrete retstvister umiddelbart langt vigtigere end Højesterets dommere. Til sammenligning kan det nævnes, at man som borger i EU kan finde oplysninger om samtlige dommeres erhvervsprofil inden for alle tre EF-domstole, nemlig De Europæiske Fællesskabers Domstol, Retten i Første Instans og EU-Personaleretten (www.curia.europa.eu).

Tallene om dansk dommerrekruttering taler i vidt omfang for sig selv. Den samlede konklusion er, at der tale om en beskeden udvikling i rekrutteringsmønsteret. I perioden fra 2003 til 2008 er cirka $83 \%$ af de udnævnte dommere jurister blevet rekrutteret fra domstolene selv eller Justitsministeriets regi. Hvis de udnævnte dommere med overvejende baggrund fra Procesbevillingsnævnet og politi- og anklagemyndighed lægges hertil, bliver tallet endnu højere. Tallet på $95 \%$ fra Domstolsudvalgets betænkning fra 1996 har altså på godt 10 år ændret til et tal på cirka $85 \%$, nemlig den aktuelle andel af dommere med baggrund i den traditionelle dommerkarrieremodel. Udviklingen er med andre ord præget af en vis træghed.

I forhold til den fortsat relativt snævre dommerekruttering til byrets- og landsretsniveau er der grund til at minde om, at Domstolsudvalget i 1996 lagde særlig vægt på målsætningen om bredt erfaringsgrundlag hos dommere i de retsinstanser, der er kollegiale, dvs. landsretterne og Højesteret. I disse domstole sidder der som udgangspunkt henholdsvis tre og fem dommere på dommerpodierne. Med domstolsreformen af 2007 er der dog sket den vigtige ændring, at også byretterne kan beslutte at optræde som en kollegial domstol med tre dommere på podiet. Det er således hævet over enhver tvivl, at målet om alsidig rekruttering også gælder for byretterne.
Den nye gruppe af jurister, som har fået adgang til dommerstillinger, er advokaterne. Andelen af de udnævnte dommere, der har tidligere overvejende advokatansættelse, er cirka $12 \%$. En række af de udnævnte advokater har i øvrigt tidligere været ansat i Justitsministeriet. Tallet på $12 \%$ er ud fra hidtidig rekrutteringspraksis i Danmark relativt højt, men dog ikke imponerede i forhold til andre europæiske lande. Dommere i f.eks. de angelsaksiske lande rekrutteres primært blandt advokater, og i Norge har 30-40\% af de nyudnævnte dommere haft advokatbaggrund i perioden fra 2003 til 2007. Den hidtidige danske udvikling kan heller ikke på denne internationale baggrund antages at opfylde målsætningen om alsidig og bred rekruttering.

I forhold til andelen af jurister fra de øvrige ansættelsesmæssige områder, har målsætningen indtil videre haft næsten intet gennemslag. Der gælder jurister fra f.eks. andre fagministerier end Justitsministeriet, den kommunale sektor, privat ansættelse, internationale organisationer, interesseorganisationer og universiteterne. I forhold til jurister med overvejende erfaring fra ansættelse i andre fagministerier end Justitsministeriet er der ud fra det oplyste blevet indstillet en jurist med sådan baggrund. Målet om bredere rekruttering er fortsat helt uopfyldt her.

\section{Kønsmæssig diversitet}

Det overordnede billede af nyudnævnte dommeres fordeling på køn er relativt entydigt, da Dommerudnævnelsesrådet indstiller og Justitsministeren udnævner flest kvindelige jurister til dommerstillinger ved byretterne og flest mandlige jurister til landsretter og Højesteret.

Tabel 3: Procentvis andel af kvinder i de forskellige domstolsniveauer fra 2003-2008

\begin{tabular}{|l|l|l|l|}
\hline & Byret & Landsret & Højesteret \\
\hline 2008 & $57 \%$ & $20 \%$ & Ingen nye dommere \\
\hline 2007 & $67 \%$ & $33 \%$ & Ingen nye dommere \\
\hline 2006 & $51 \%$ & $0 \%$ & $0 \%$ \\
\hline 2005 & $87 \%$ & $40 \%$ & $0 \%$ \\
\hline 2004 & $41 \%$ & $0 \%$ & $100 \%$ \\
\hline 2003 & $53 \%$ & $33 \%$ & $0 \%$ \\
\hline I alt 03-08 & $56 \%$ & $23 \%$ & $20 \%$ \\
\hline
\end{tabular}

På grundlag af tallene frem til 2008 kan man med andre ord konstatere, at der endnu ikke er ligestilling ved danske domstole, men at udviklingen synes at gå i den rigtige retning. Hvis der er en udviklingstendens for tiden, er det således et stigende antal kvinder ved byretterne, som også har fåt mange flere sager at ekspedere efter domstolsreformen i 2007. Ud af de mange nyudnævnte byretsdom- 
mere fra 2006 til 2008 udgør kvinderne tæt på $60 \%$. Ud af samtlige fungerende byretsdommere landet over er dog kun $47 \%$ i dag kvinder. I forhold til landsretterne og Højesteret er det fortsat mændene, der udgør flertallet. Der er dog kommet lidt flere kvindelige jurister ind i landsretterne de senere år. Hvis man ser på alle fungerende landsdommere og højesteretsdommere, udgør kvinderne henholdsvis $30 \%$ og $19 \%$. I både den norske og svenske højesteret er andelen af kvinder markant højere, nemlig henholdsvis $37 \%$ og $50 \%$. Til sammenligning er det interessant, at det underordnede juridiske personale ved domstolene er kvinder. Siden 2007 har kvinderne udgjort mere en halvdelen af de ansatte i retsassessor-stillinger, som rangerer lige under dommerstillingen. Der er $69 \%$ kvinder blandt dommerfuldmægtigene, som befinder sig yderligere et trin nede i dommerhierarkiet.

Set i retshistorisk perspektiv er udviklingen i kønsfordelingen den mest fundamentale ændring af domstolssystemet overhovedet. Kvindelige jurister fik i 1921 adgang til at blive udnævnt til dommer, men det blev en del år senere, at de reelt fik stillinger. De første udnævnelser af kvinder til byretsdommer og landsdommer kom i 1939, og den første kvindelige danske højesteretsdommer blev udnævnt i 1953, de to næste i 1964 og 1982. Indtil for godt 10 år siden var kønsfordelingen fortsat helt skæv, da $75 \%$ af byretsdommerne var mænd, og da mere end 80 $\%$ af dommerne i landsretterne og Højesteret var mænd. Selv om den igangværende udviklingstendens i det perspektiv er positiv, kan det diskuteres, om de opnåede konkrete resultater opfylder mål om bred rekruttering og ligestilling.

I DJØF-rapporten fra 2008 „Vi kan ikke bare vente“ konkluderes det, at $45 \%$ kvinder blandt nyudnævnte djøfledere i den offentlige sektor er for lidt. I både landsretter og Højesteret må man altså konstatere, at dette mål slet ikke er opfyldt. Så klar en konklusion når man dog ikke i Domstolsstyrelsens ligestillingsrapport fra 2007. Her anføres det, at skævheden i kønsfordelingen i dommerstillinger navnlig må „tilskrives, at der blandt de jurister, der anciennitetsmæssigt kan komme i betragtning til disse stillinger, hidtil har været relativt færre kvinder". Om vejen mod bred rekruttering og ligestilling kan sættes på en så enkel formel, er dog i mine øjne tvivlsomt. Realiteterne viser faktisk det modsatte, da kvinder allerede nu udgør flertallet af de jurister, som kan rekrutteres til dommerpodiet. Flertallet af juridiske kandidater fra danske jurafakulteter har siden 1987 været kvinder. Til sammenligning var $49 \%$ af alle nye norske dommere i 2007 kvinder, selv om kvinderne kun udgjorde en 1/3 af ansøgerfeltet.

\section{Ansøgergrupper til dommerstillinger}

Den aktuelle dommerrekruttering skal ses i lyset af, hvilke jurister der søger stillinger som dommere. Her er der som noget nyt i 2009 offentliggjort en række statistiske og generelle oplysninger om de udnævnelser, der fandt sted i 2008. Disse oplysninger har tidligere ikke været tilgængelige, men Dommerudnævnelsesrådet har efter faglig kritik af denne mangel i sin årlige afrapportering (se Michael Gøtze, 2008a) nu skabt lidt større åbenhed om rekrutteringsgrundlaget. Billedet er dog ikke entydigt, og dele af de offentliggjorte oplysninger er relativt svære at afkode. Dommerudnævnelsesrådet forklarer ikke de statistiske oplysninger noget steds, hvad der ellers kunne skabe større klarhed. Desuden savner man et sammenligningsgrundlag for 2008, da tidligere års ansøgerfelter fortsat er helt uoplyste. Oplysningerne om ansøgerfelt vedrører erfaringsmassen og er ikke knyttet til personer som sådanne. Det er klart, at offentligheden ikke kan forlange oplysninger om konkrete personer.

Det fremgår af Dommerudnævnelsesrådets oplysninger, at antallet af ansøgere varierer på de forskellige domstolsniveauer. I 2008 var der i gennemsnit cirka tre ansøgere til hver ny stilling som byretsdommer, mens ledige landsdommerstillinger i gennemsnit tiltrak cirka seks ansøgere. Dette er den klareste del af oplysningerne. I forhold til faglig profil er det dommerfuldmægtige, der udgør den største gruppe af ansøgere til byretterne, idet godt $2 / 3$ af erfaringsmassen hos ansøgerne vedrører denne erhvervsbaggrund. Desuden søger især advokater og jurister fra Justitsministeriet ind på dette trin i domstolspyramiden.

Ansøgerne til dommerstillinger i landsretterne er for $46 \%$ vedkommende byretsdommere og dommerfuldmægtige, som altså håber på forfremmelse. Kun $40 \%$ af de nyudnævnte dommere i landsretterne i 2008 har dog denne profil, så tallene må forstås sådan, at der bliver givet flere stillingsafslag til jurister med denne erhvervsprofil. Jurister med ansættelsesmæssig erfaring fra Justitsministeriet udgør $19 \%$ af ansøgerne til landsretterne, og de synes at have klart større succes med deres ansøgninger, da $40 \%$ af de nyudnævnte landsdommere i 2008 har primær erhvervsmæssig baggrund fra Justitsministeriet. Advokaterne udgør i $200820 \%$ af ansøgerne til landsretterne, og de udgør også $20 \%$ af de nyudnævnte landsdommere. Det kan ikke umiddelbart udledes af tallene fra 2008, om f.eks. samtlige ansøgere fra Justitsministeriet til stillinger som landsdommer også blevet indstillet og udnævnt. Tallene vedrører som nævnt erfaringsmassen generelt, og ikke enkeltpersoner. De offentliggjorte statistiske oplysninger kan på den anden side heller ikke læses som dokumentation for, at det $i k k e$ forholder sig sådan. Hvis rekrutteringsfrekvensen er så høj som f.eks. 
$100 \%$ for ansøgere fra Justitsministeriet, er det i sig selv et interessant element i debatten om alsidig rekruttering.

\section{Dommerkulturen i embedsmandsdomstole}

En vigtig dimension i udviklingen ved domstolene er udviklingen i dommerkulturen. Det er et indholdsmæssigt punkt i debatten om fornyelse af rekrutteringsmønstre, som desværre ofte overses. Dette fravær af debat skyldes som udgangspunkt, at oplysningerne i Dommerudnævnelsesrådets beretninger om dommernes individuelle og formelle erhvervsmæssige baggrund i en vis forstand er fragmentariske og således ikke kan udgøre et grundlag for at sige noget om, hvorvidt den dominerende dommerkultur er under forandring. Det siger naturligvis sig selv, at en åbning af rekrutteringen ikke uden videre er ensbetydende med en modernisering af domstolene rent indholdsmæssigt i forhold til f.eks. en mere dynamisk anvendelse af juraen. Alsidigheden er først en realitet, hvis og når en mere alsidig rekruttering til dommerstanden slår igennem i det praktiske retsarbejde og bidrager til at skabe mere faglig dynamik i det konkrete arbejde med regelfortolkninger og bevisvurderinger.

Hvis dommere skal "tænke mere ud af boksen“, som det ofte fremhæves i debatten om modernisering af domstolsvæsenet, er det klart, at en sådan faglig kompetence skal indgå i f.eks. dommeruddannelsen og dommertænkningen generelt. Dommerkulturen er dog et meget kontroversielt punkt i debatten om fornyelse af domstolssystemet, og det er blevet anført af Dommerudnævnelsesrådets formand, højesteretsdommer Lene Pagter Kristensen, at en ændring af kulturen ikke indgår som led i rekrutteringsreformen fra 1998 (se udtalelse fra Dommerudnævnelsesrådet i Justitsministeriets svar af 20. juni 2008 på spørgsmål nr. 783 af 27. maj 2008 (Alm. del) fra Folketingets Retsudvalg om udviklingen i dommerrekrutteringen). Dette begrundes bl.a. med, at dommerkulturen ikke udtrykkeligt omtales af f.eks. Domstolsudvalget. En sådan udlægning af teksten er efter min opfattelse noget formalistisk og overfladisk i forhold til Domstolsudvalgets reformønsker. Da den seneste domstolsreform fra 2007 eksplicit lægger op til en ændring af dommerkulturen på visse vigtige områder, jf. nedenfor, er det i øvrigt vanskeligt at opretholde et synspunkt om en uforandret dommerkultur.

Som udgangspunkt er der ikke tvivl om, at flere dele af dommerkulturen i danske domstole bygger på en embedsmandskultur. I og med at danske domstole traditionelt har været netop embedsmandsdomstole med embedsmænd som dommere, er denne kultur for så vidt et rodfrestet kendetegn ved domstolssystemet. Selv om en del dommere rekrutteres fra domstolene selv og dermed har gennemgået en uddannelse som dommerfuldmægtig, er denne dommeruddannelse i vidt omfang stadig præget af embedsmandsuddannelsen. Også den uddannelse, der foregår i landsretterne af midlertidige dommere, de såkaldte konstituerede landsdommere, bærer fortsat træk af traditionel embedsmandsskoling. Her kan der nævnes elementer som oplæring i hierarkitænkning, herunder tæt supervision af dommerspirer i form af monitorering af alt skriftligt og mundtligt arbejde. Hertil kommer en række ofte uformelle forventninger om forsigtighed i forskellige varianter i det juridiske arbejde.

Et konkret udtryk for den embedsmandslignende dommerkultur findes i dissenskulturen ved danske domstole, som er blevet undersøgt nærmere (se Eigil Lego Andersen 2003). Hvis en retssag behandles af flere dommere, er der som bekendt mulighed for dissens og faglig uenighed blandt dommere. Da mange sager beror på konkrete afvejninger, er der en formodning for, at der forekommer dissens i en del sager, ikke mindst i principielle og tvivlsomme sager. Dog viser de empiriske undersøgelser af dissenskulturen, at udgangspunktet ofte er det modsatte, nemlig tendens til konsensus. Ligesom embedsmænd synes dommere at foretrække enighed og enstemmighed. I Højesteret afgiver dommerne dissens i $22 \%$ af de ordinære højesteretssager, og de fem højesteretsdommere er således enige i $78 \%$ af sagerne.

Selv om spørgsmålet om dommerkulturen er omtvistet blandt jurister, er der grund til at pege på, at et ønske om ændret dommerkultur som nævnt er indbygget $\mathrm{i}$ den seneste domstolsreform. Det gør sig bl.a. gældende i forhold til de allerede nævnte nye regler i retsplejeloven om mulighed for kollegial dommerbehandling af sager ved byretterne. Da byretterne efter reformen er blevet indgangen til alle retssager uanset art, kan byretterne beslutte, at vanskelige og principielle sager skal bedømmes af tre dommere, og ikke kun én dommer. Et vigtigt delområde for kollegial behandling er f.eks. sager, hvori der indgår vanskelige EU-retlige spørgsmål. De EU-retlige regler har i teorien i mange år været del af dansk ret, men noget tyder på, at den EU-retlige regulering i både domstols- og f.eks. forvaltningssystemet på forskellige områder i praksis anses for at have ingen eller i hvert fald en meget lav retlig status. Denne nye regel om kollegial bedømmelse i bl.a. EU-sager er reelt et forsøg på at gøre op med en uformel tradition i dele af domstolssystemet for, at fortolkning af EU-retlige regler anses for at være et anliggende for Højesteret, $i k k e$ for byretter eller landsretter. En modernisering af domstolene forudsætter her en forandring af selve dommerkulturen.

I forhold til EU-retten er det også interessant, at danske domstole er nationalt orienteret i den forstand, at dommerne som udgangspunkt selv finder ud, hvordan EU-lovgivning og EU-praksis skal fortolkes. Det er 
i den forbindelse blevet anført, at adgangen til at sende udvalgte fortolkningsspørgsmål i formel høring hos EUdomstolen i Luxembourg inden for rammerne af den såkaldte præjudicielle forelæggelse kun udnyttes i begrænset omfang. Dette viser en række empiriske undersøgelser (se Marlene Wind m.fl. 2009). Det konkrete antal årlige forelæggelser ligger mellem 3-5 de seneste fem år, hvad der kan skyldes både saglige og mindre saglige grunde. Forelæggelsesfrekvensen kan bl.a. sættes i forhold til, at en stor del af moderne lovgivning - formentlig cirka $20 \%$ - stammer fra EU. Hertil kommer, at der hvert år passerer flere tusinde sager gennem det danske domstolssystem, hvad der rent fagligt burde aktualisere en vifte af EUretlige problemstillinger. Hvad der præcist er årsagen til denne fortsat overvejende nationale fortolkningskultur er vanskeligt at sige, men der er peget på, at den begrænsede trafik mellem danske domstole og EF-domstolen synes at være påvirket af et embedsmandsudvalg under Justitsministeriet med ekspertise på området, nemlig Juridisk Specialudvalg. Dette udvalg har generelt valgt en tilbageholdende kurs i forhold til muligheden for forelæggelser. Uanset om det må lægges til grund, at dommere - hvoraf en stor del har trådt deres professionelle barnesko i netop dette ministerium - måtte tage en vis pejling af dette udvalg, er domstolenes arbejde med EU-sager af stor interesse for udviklingen af en moderne dommerkultur.

\section{På vej mod åbning af dommerrekrutteringen - trods barrierer?}

Trægheden i udviklingen i dommerrekruttering giver anledning til mange overvejelser. I den forbindelse kan det nævnes, at et udvalg under Domstolsstyrelsen - Visionsudvalget for Domstolsjurister - i 2007 afgav en rapport om xndringer og nye tiltag inden for karriere- og kompetenceudvikling for jurister ansat ved Danmarks domstole. Udvalget understeger, at der bør stræbes efter en bred rekruttering, og rapporten indeholder mange gode forbedringsforslag i den henseende. Hvis disse tiltag implementeres, er der tale om fremskridt. Der er som opfølgning på rapporten endvidere nedsat et antal karriereudvalg under Domstolsstyrelsen med medarbejdere fra domstolene, som skal konkretisere de forskellige visioner. På baggrund af de nye tal fra 2008 er det grundlæggende spørgsmål dog fortsat, om det er tilstrækkeligt

Generelt er der behov for belysning af faktiske barrierer for en bred dommerrekruttering. Domstolsstyrelsen kunne her være egnet til at igangsætte en reel undersøgelse. Umiddelbart er der en formodning for, at dommeransættelsen har appel til et bredt udsnit af jurister. Ansættelsesmæssigt nyder dommerne en grundlovssikret og dermed helt unik sikkerhed, hvortil kommer, at dommerjobbet i praksis omfatter en række frihedsgrader med henblik på at give dommere mulighed for at påtage sig bijobs. Rent fagligt er dommergerningen kendetegnet ved berøring med alle slags sager inden for det civilretlige og strafferetlige område, og den faglige udfordring er derfor relevant for en bred kreds af jurister. I forhold til kønsfordelingen blandt nyudnævnte dommere er der behov for særlig analyse af faktiske barrierer for kvindelige jurister i forhold til landsretter og Højesteret. Det er overraskende, at andelen af kvinder er så relativt lav i betragtning af, at der i over tyve år har været et flertal af kvinder i juristmiljøet, og at dommerstillinger rent ansættelsesmæssigt er attraktive for både kvinder og mænd.

Det er her bemærkelsesværdigt, at den oftest fremførte barriere fra domstolssystemet selv er lønforhold (se Lene Pagter Kristensen 2008). Hovedsynspunktet er, at den snævre rekruttering i høj grad beror på, at dommeransættelsen ikke er lønmæssigt attraktiv for de jurister, der rent fagligt og anciennitetsmæssigt må antages at have mulighed for at foretage et karriereskift til domstolsbranchen. Selv om en årsløn i omegnen af 1 mio. kr. for dommere kan repræsentere et tilbageslag for visse privatansatte jurister, først og fremmest advokater i København, bliver den lønmæssige barriere efter min opfattelse ofte overbetonet i rekrutteringsdebatten. Udover at et rent pekuniært argument om for lav dommerløn kan forekomme en anelse forkælet, kan aflønningen næppe forklare alle grundlæggende mønstre i den eksisterende rekruttering. Det er f.eks. vanskeligt at forstå, hvordan en eventuel lønmæssig barriere kan forklare, at jurister fra Justitsministeriets ressortområde rekrutteres uden nævneværdige problemer - men ikke andre dele af det brede offentlige ansættelsesområde - til dommerstillinger i landets retssale.

Samlet set er der grund til at fastholde og udbygge det momentum, der trods alt synes at præge rekrutteringen. Selv om den klare politiske målsætning om større diversitet i dommerkorpsets erfaringsgrundlag endnu ikke er indfriet, er der trods alt sat et momentum i gang. Det er især værd at bemærke de nye dommere med advokaterfaring, som muligvis med tiden kan trække andre advokater og andre juristgrupper med sig ind i domstolssystemet. Med den nuværende udviklingstakt er målet om bred rekruttering måske realiseret om et par generationer. Der er efter min opfattelse grund til at håbe, at de nye og gode initiativer fra bl.a. Domstolsstyrelsen kan fremskynde processen. Uanset at en åben rekruttering er et kontroversielt spørgsmål, herunder for domstolssystemet selv, har domstolene principielt en interesse i at styrke sin legitimitet og uafhængighed som statsmagt i et moderne retssamfund. 


\section{Referencer}

Andersen, EL 2003, 'Dissensmønstre i Højesteret 1991-2001', in Hyldestskrift til Jørgen Norgaard, DJØFs Forlag, København.

Betænkning nr. 1319/1996, herefter Domstolsudvalgets betænkning.

Christensen, JP 2003, Domstolene-Den tredje statsmagt.

Dommerudnævnelsesrådetsårsberetninger http://www.domstol.dk/ Dommerudnaevnelsesraadet

EU-Domstolen, http://www.curia.europa.eu

Gøtze, M 2008a, 'Dommerrekruttering i et udviklingsperspektiv', in Festskrift til Jørn Vestergaard, DJØFs Forlag, København.

Gøtze, M 2008b, 'Dommerrekruttering, Operation Morgenluft i dommerstanden har åndenød', Advokaten no. 42008.

Hammerslev, $\mathrm{O}$ 2003, Danish Judges in the 20th Century, DJØF Publishing, København.

Justitsministeriets svar af 20. juni 2008 på spørgsmål nr. 783 af 27. maj 2008 (Alm. Del) fra Folketingets Retsudvalg om udviklingen i dommerrekrutteringen.
Kristensen, LP 2008, 'Står det nu også så galt til med dommerrekrutteringen?', Advokaten no.7 2008.

Malleson, K \& Russell, PH (ed.) 2006, Appointing Judges in an Age of Judicial Power: Critical Perspectives from around the World, University of Toronto Press, Toronto.

Norges domstole http://www.domstol.no

Rapport afgivet af Visionsudvalget for Domstolsjurister, Domstolsstyrelsen, september 2007.

Retsplejerådets betænkninger I-V om reform af den civile retspleje nr. 1401/2001, nr. 1427/2003, nr. 1436/2004, nr. 1468/2005 og nr. $1481 / 2006$.

Sveriges domstolar http://www.domstol.se

Tellesbø, O 2006, 'Hvorfor Høyesterett er statsvennlig', Retfard no. 4, vol.115, pp. 65- 78 .

Wind, M; Martinsen, DS \& Rotger, GP 2009, 'The Uneven Push for Europe: Questioning Variation when National Courts go to Europe', European Union Politics Volume 10, pp. 63-88. 